\title{
Pemodelan dan Prediksi Kebutuhan Logistik Pasca Bencana di Sumatera Barat
}

\author{
Taufik Martha ${ }^{1}$, Purnawan ${ }^{2}$, Hendra Gunawan ${ }^{3}$ \\ Fakultas Teknik, Universitas Andalas, Padang ${ }^{1}$, Jurusan Teknik Sipil, Fakultas Teknik, Universitas \\ Andalas Padang ${ }^{2,3}$ \\ Email: taufikmartha90@gmail.com¹, purnawan@gmail.com², hendra@ft.unand.ac.id ${ }^{3}$ \\ DOI: http://dx.doi.org/10.31869/rtj.v4i1.2292
}

\begin{abstract}
Sumatera is one if the areas that is located in the high land. Geographically, it is lied in the volcanic high land that is formed by Bukit barisan Mountain range Sumatera Barat which is rich in natural resources. But unfortunately, due ti its location, West Sumatera has also potentials to various natural disasters like earth quake, tsunami, landslide, land movement, flood and fire if compared to other areas as mentioned in National Action Plan for Disaster Risk Reduction 2012. There have been many preventive actions that have been done by the government. However, those actions are not accompanied by disaster logistics improvement. Modelling is undergone by optimizing the needs pf disaster logistics by considering the characteristics of disaster prone areas. This research is intended to predict the logistics needs by optimizing the needs of disaster victims in west sumatera. The method used is regression analysis by predicting yearly disaster logistics needs. The result of this research showed that the best mode is $Y=401.81+0.001 X 1+14.55 X 6+37.58 X 9-10.53 X 14$ with the prediction increase of the logistics needs for about $2.3 \%$ every year.
\end{abstract}

Key words: Modelling, Logistics, Disaster.

\section{PENDAHULUAN}

Sumatera Barat merupakan salah satu daerah yang berada pada daratan tinggi di Indonesia. Dilihat dari letak geografis Sumatera Barat tepat pada daratan tinggi vulkanik yang dibentuk oleh bukit barisan yang kaya dengan sumber daya alam, namun sebaliknya berdasar letak geografis itu pula Sumatera Barat juga mempunyai potensi bencana alam yang sangat beragam dibanding daerah lain. Potensi bencana alam di Sumatera Barat yang sangat beragam tertuang dalam National Action Plan for Disaster Risk Reduction 2012 dengan menyebutkan bahwa berdasarkan pada kejadian dan dampak yang ditimbulkan selama 2 dekade terakhir, Sumatera Barat berpotensi terhadap bencana gempa bumi, tsunami, tanah longsor dan gerak tanah, erupsi gunung api, banjir dan kebakaran.

Besarnya intensitas bencana terus meningkat dari waktu kewaktu, sesuai dengan data yang dihimpun dari Badan Pusat Statistik (BPS) Propinsi Sumatera Barat, dapat dilihat pada Gambar 1

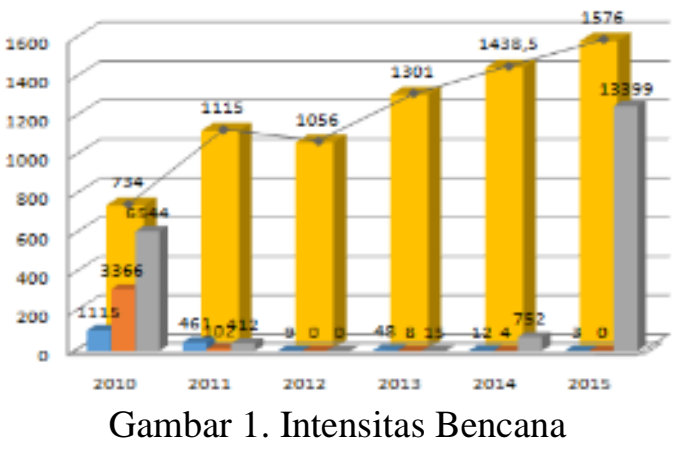

Sumber: BPS Propinsi Sumatera Barat, 2015.

Setiap tahunnya frekuensi bencana terus meningkat untuk semua jenis bencana alam di Sumatera Barat, baik bencana alam tunggal ataupun bencana alam yang terjadi secara bersamaan. Seperti halnya kejadian bencana gempa bumi ditahun 2010 (99 kejadian) kemudian berturut turut tahun 2011(116 kejadian), 2012 (311 kejadian), 2013 (330 kejadian), 2014 (302 kejadian), dan 2015 (302 kejadian). Dibandingkan dengan jenis bencana lain, gempa mempunyai efek paling besar terhadap rusaknya area terkena bencana, terutama sarana dan prasarana serta hunian penduduk. Gempa juga mempunyai kemungkinan diikuti dengan bencana lain seperti longsor, kebakaran ataupun tsunami

Menurut gutavson (2003), bencana alam tidak hanya merusak bangunan secara fisik, namun juga akan mempengaruhi mental dan 
keadaan social dari masyakat yang terkena bencana. Kekurangan makanan, obat obatan, penyebaran penyakit pasca bencana dan kebutuhan untuk tempat berlindung sebagai pengganti rumah yang tidak bisa ditempati menyebabkan keadaaan social yang terpengaruh oleh bencana ini biasanya diperparah dengan lambatnya penaganan korban bencana dan pengiriman bantuan.

Penelitian tentang pengembangan model distribusi logistik juga telah pernah dilakukan Arief (2013) tentang pengembangan model distribusi barang bantuan kepada korban bencana dengan mempertimbangkan pengaruh banyaknya jumlah barang donasi, kapasitas tempat penyimpanan, sarana transportasi, serta karakteristik barang bantuan. Dari hasil studi terlihat bahwa untuk mempercepat waktu memenuhi permintaan dan mengurangi jumlah persediaan di seluruh depo dengan menggunakan berbagi persediaan, sehingga menghasilkan waktu yang lebih baik bila dibandingkan masukkan donasi yang sama tanpa berbagi persedian pada semua besaran donasi.

Pemodelan dan memprediksi kebutuhan logistic pasca bencana menggunakan analisis regresi berganda dengan data yang digunakan diperoleh diperoleh dari data BPS tahun 2015. Penelitian ini bertujuan untuk memprediksi jumlah korban dan kebutuhan logistic pasca bencana, dimulai dengan memprediksi jumlah korban bencana baik itu korban mengungsi ataupun korban cidera

\section{METODE PENELITIAN}

Alur pikir pelaksanaan penelitian ini secara sederhana dapat di ilustrasikan pada diagram alir berikut ini.

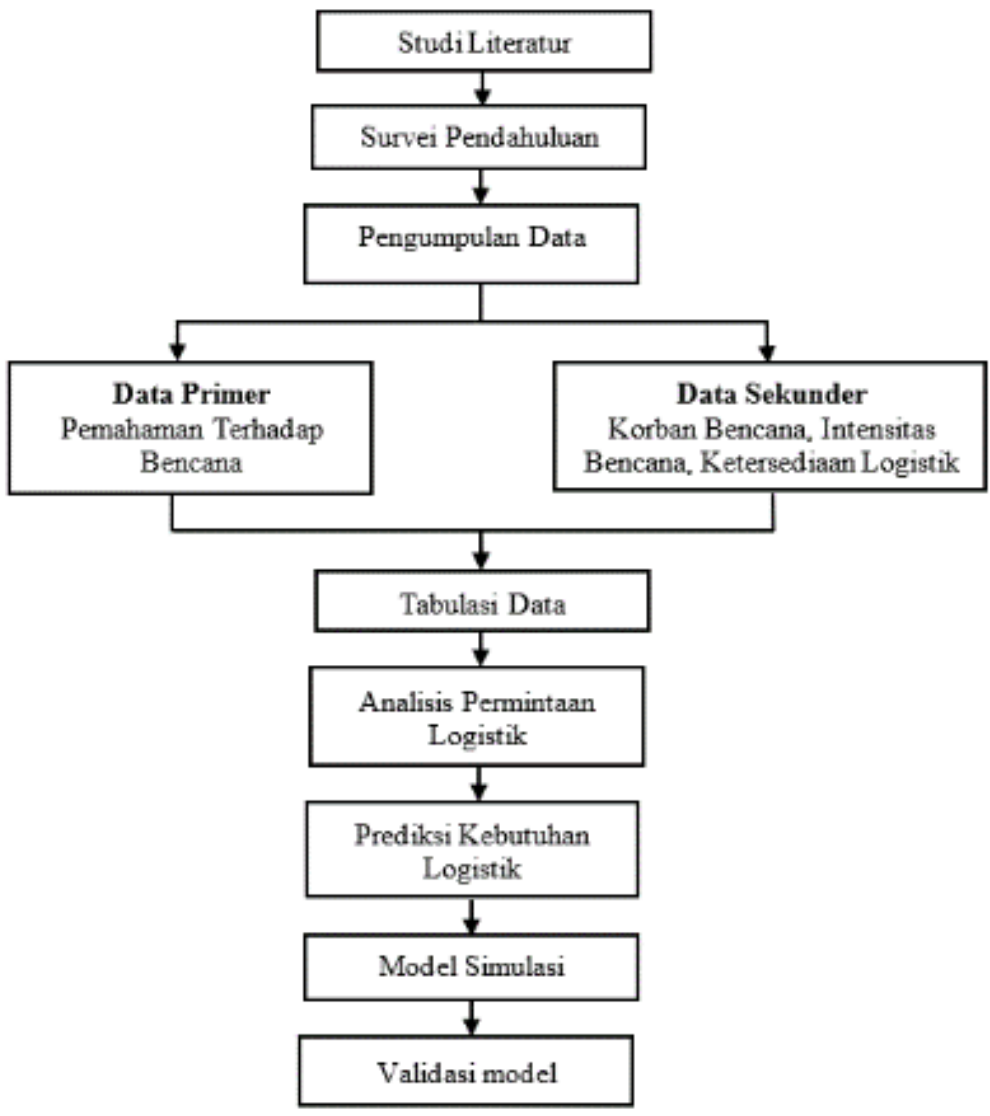

Gambar 2. Diagram Penelitian

Alur pikir pelaksanaan penelitian pemodelan dan simulasi pendistribusian logistic ini menggunakan parameter yang didapatkan dilapangan. Secara umum tujuan penelitian ini adalah sebagai berikut:

1. Untuk memprediksi jumlah korban pasca bencana.
2. Memprediksi kebutuhan logistic korban bencana.

Untuk memprediksi jumlah kebutuhan logistik terlebih dahulu dilakukan prediksi pada korban bencana dengan pendekatan metode regresi. Peramalan dengan menggunakan metode regresi dibutuhkan 
kandidat variabel bebas dan variabel tak bebas. Variabel bebas umumnya merupakan faktorfaktor yang mempengaruhi variabel tak bebas.

Jadi dengan kata lain penggunaan tabulasi silang pada awal penelitian ini merupakan langkah awal untuk mengetahui variabel yang berpengaruh dan tidak berpengaruh pada prediksi korban bencana. Analisis ini dilakukan dengan uji statistik dengan tahapan sebagai berikut:

- Untuk mengetahui hubungan antara variable bebas dengan variable tak bebas pada setiap variable menggunakan metode regresi linear berganda. Dengan koefisien regresi linear berganda menggunakan metode kuadran terkecil dinyatakan dalam bentuk persamaan linear 1,2 , 3 , dan 4.

$\sum \varepsilon i^{2}=\sum\left(Y i=\beta_{0}+\beta_{1} X_{1}+\beta_{2} X_{2}\right.$

Dimana variabel yang digunakan seperti berikut:

y3 = korban mengungsi

b1, b2..bn=koefisienparameter model

$\mathrm{b} 0=$ konstanta

$\mathrm{x} 1=$ jumlah penduduk

$\mathrm{x} 2=$ kepadatan penduduk

$\mathrm{x} 3$ =jumlah pelayanan kesehatan

$\mathrm{x} 4=$ peralatan evakuasi

$\mathrm{x} 5=\mathrm{PDRB}$

$\mathrm{x} 6$ = gempa bumi

$\mathrm{x} 7=$ daerah rawan tsunami

$\mathrm{x} 8=$ tanah longsor

$\mathrm{x} 9=$ banjir

$\mathrm{x} 10=$ kebakaran

$\mathrm{x} 11=$ abrasi pantai

$\mathrm{x} 12=$ angin puting beliung

$\mathrm{x} 13$ = pemahaman baik

$\mathrm{x} 14=$ pemahaman kurang baik

- Untuk mengetahui keeratan dan kekuatan hubungan antara kedua variable $\mathrm{x}$ dengan variable y maka digunakan nilai korelasi, sedangkan besarnya pengaruh $\mathrm{x}$ terhadap $\mathrm{y}$ diukur dengan dengan koefisien regresi.

$$
r_{x y}=\frac{\sum(X i-\bar{X}) \cdot(Y i-\bar{Y})}{\left[\sum(X i-\bar{X})^{2} \cdot \sum(Y i-\bar{Y})^{2}\right]^{1 / 2}}
$$

- Untuk mengetahui tingkat linearitas pada regresi yang digunakan maka dilakukan uji signifikansi dengan Ftest dan T-test.

$$
R^{2}=\frac{\left[n \sum x y-\sum x \sum y\right]^{2}}{n \sum x^{2}-\left(\sum x\right)^{2}+n \sum y^{2}-\left(\sum y\right)^{2}}
$$

Dan

$$
t=\frac{b-\beta}{S b}
$$

$$
\left.+\beta_{n} X_{n}\right)^{2}{ }_{F}=\frac{J K R / k}{\frac{J K S}{n}-k-1}=\frac{\sum(\hat{Y}-\bar{Y})^{2} / k}{\sum(Y i-\hat{Y})^{2} / n-k-1}
$$

Setelah model itu didapat maka langkahlangkah selanjutnya adalah menggunakan model untuk memprediksi jumlah kebutuhan logistik pada tahun-tahun mendatang. Sebagai input datanya variable bebasnya adalah nilai tahun (2010, 2011, 2012, 2013 dan 2014).

Untuk memprediksi jumlah kebutuhan logistik pada hari 1-5 hari pasca bencana, kondisi dalam penanganan korban berbagai jenis bencana alam, yaitu memberikan kebutuhan pangan secepat mungkin dan kebutuhan pangan yang dibutuhkan. Jenis kebutuhan logistik pasca bencana awal dan tiap jenisnya dapat diformulasikan dalam pemodelan matematis dengan pemodelan program linear. Variabel keputusannya adalah jumlah tiap logistik yang dibutuhkan berdasarkan kategori (pria, wanita, anak anak dan balita). Fungsi tujuan adalah menentukan total tiap kebutuhan logistik. Jumlah penduduk pria, wanita, anak dan balita menjadi konstanta dari variable keputusan berdasarkan kategorinya. Formulasi matematis yang terbentuk dapat dilihat pada persamaan 5 .

$$
\mathrm{Z} \_\mathrm{i}=\mathrm{a} \_1 \text { x_1 }+\mathrm{a} \_2 \quad \mathrm{x} \_2+\mathrm{a} \_3 \quad \mathrm{x} \_3+\mathrm{a} \_4
$$

x_4

Dimana:

$$
\begin{array}{ll}
\mathrm{i} & =\text { jenis logistik } \mathrm{k}-\mathrm{i} \\
\mathrm{a} 1 & =\text { jumlah pria dewasa }
\end{array}
$$


a2 = jumlah wanita dewasa

a3 = jumlah anak anak

$\mathrm{x} 1=$ jumlah kebutuhan untuk pria

$\mathrm{x} 2$ =jumlah kebutuhan wanita

$\mathrm{x} 3$ = jumlah kebutuhan anak

$\mathrm{x} 4$ = jumlah kebutuhan balita

$\mathrm{Z}$ = fungsi tujuan

Dalam penentuan jenis kebutuhan logistik untuk lima hari pasca bencana diformulasikan jumlah logistik yang dibutuhkan berdasarkan peraturan BNPB no 7 tahun 2008 danPUGS (Pedoman Umum Gizi Seimbang) adalah sebagai berikut:

1. Pangan

- Beras

Bantuan makanan diberikan dalam bahan makanan yang berupa beras \pm 360 gr dengan kebutuhan perharinya sebagai berikut:

$\mathrm{Y}=0,36 x_{1}+0,36 x_{2}+0,24 x_{3}+0.24 x_{4}$

$\mathrm{Y}=$ jumlah beras yang dibutuhkan

$(\mathrm{kg})$

$x_{I}=$ jumlah pengungsi dewasa pria

$0.36 \mathrm{~kg} / \mathrm{hr}$

$x_{2}=$ jumlah pengungsi dewasa wanita

$0.36 \mathrm{~kg} / \mathrm{hr}$

$x_{3}=$ jumlah pengungsi anak-anak

$0.24 \mathrm{~kg} / \mathrm{hr}$

$x_{4}=$ jumlah pengungsi balita

$0.24 \mathrm{~kg} / \mathrm{hr}$

Bantuan pangan berupa beras diberikan kepada korban mengungsi selama pasca bencana yaitu lima hari.

- Mie instan

Bantuan makanan diberikan dalam bahan makanan yang berupa mie instant $\pm 85 \mathrm{gr} /$ bungkus dengan kebutuhan perharinya sebagai berikut:

$\mathrm{Y}=x_{1}+x_{2}+x_{3}+x_{4}$

$\mathrm{Y}=$ jumlah mie yang dibutuhkan (bungkus)

$x_{l}=$ jumlah pengungsi dewasa pria

$0.085 \mathrm{~kg} / \mathrm{bks} / \mathrm{hr}$

$x_{2}=$ jumlah pengungsi dewasa wanita

$0.085 \mathrm{~kg} / \mathrm{bks} / \mathrm{hr}$

$x_{3}=$ jumlah pengungsi anak-anak

$0.085 \mathrm{~kg} / \mathrm{bks} / \mathrm{hr}$

$x_{4}=$ jumlah pengungsi balita

$0.085 \mathrm{~kg} / \mathrm{bks} / \mathrm{hr}$

Bantuan pangan berupa mie instant diberikan kepada korban mengungsi selama pasca bencana yaitu dua hari.

- Nugget/ sarden

Bantuan makanan diberikan dalam bahan makanan yang berupa nugget/ sarden 500 gr dengan kebutuhan perharinya sebagai berikut:

$Y=0,5 x_{1}+0,5 x_{2}+0,5 x_{3}+0,5 x_{4}$

$\mathrm{Y} \quad=$ jumlah nugget/sarden yang

dibutuhkan (kaleng)

$x_{1} \quad=$ jumlah pengungsi dewasa pria $0.5 \mathrm{~kg} / \mathrm{hr}$

$x_{2}=$ jumlah pengungsi dewasa wanita $0.5 \mathrm{~kg} / \mathrm{hr}$

$x_{3} \quad=$ jumlah pengungsi anak-anak $0.5 \mathrm{~kg} / \mathrm{hr}$

$x_{4} \quad=$ jumlah pengungsi balita $0.5 \mathrm{~kg} / \mathrm{hr}$

Bantuan pangan berupa nugget/ sarden sebagai lauk pauik diberikan kepada korban mengungsi selama pasca bencana yaitu lima hari.

- Roti

Bantuan makanan diberikan dalam bahan makanan yang berupa roti 250 gr dengan kebutuhan perharinya sebagai berikut:

$\mathrm{Y}=0,25 x_{1}+0,25 x_{2}+0,25 x_{3}+0,25 x_{4}$

$\mathrm{Y}=$ jumlah roti yang dibutuhkan (250 gr/bungkus)

$x_{1} \quad=$ jumlah pengungsi dewasa pria $1 \mathrm{bks} / \mathrm{hr}(250 \mathrm{gr})$

$x_{2}=$ jumlah pengungsi dewasa wanita $1 \mathrm{bks} / \mathrm{hr}(250 \mathrm{gr})$

$x_{3} \quad=$ jumlah pengungsi anak-anak $1 \mathrm{bks} / \mathrm{hr}(250 \mathrm{gr})$

$x_{4} \quad=$ jumlah pengungsi balita $1 \mathrm{bks} / \mathrm{hr}(250 \mathrm{gr})$

Bantuan pangan berupa roti diberikan kepada korban mengungsi selama pasca bencana yaitu lima hari.

- Air minum kemasan

Bantuanmakanan yang berupa air minum kemesan $220 \mathrm{ml}$ dengan kebutuhan perharinya sebagai berikut:

$\mathrm{Y}=0,22 x_{1}+0,22 x_{2}+0,22 x_{3}+0,22 x_{4}$

$\mathrm{Y}=$ jumlah air yang dibutuhkan (220 gr/gelas) 
$x_{1} \quad=$ jumlah pengungsi dewasa pria

$8 \mathrm{gls} / \mathrm{hr}(220 \mathrm{ml})$

$x_{2} \quad=$ jumlah pengungsi dewasa wanita

$8 \mathrm{gls} / \mathrm{hr}(220 \mathrm{ml})$

$x_{3} \quad=$ jumlah pengungsi anak-anak $8 \mathrm{gls} / \mathrm{hr}(220 \mathrm{ml})$

$x_{4} \quad=$ jumlah pengungsi balita $8 \mathrm{gls} / \mathrm{hr}(220 \mathrm{ml})$

Bantuan pangan berupa air minum kemasan diberikan kepada korban mengungsi selama pasca bencana yaitu lima hari.

2. Sandang

- Baju atau kaos

Pria mendapatkan satu baju atau kaos setiap hari sedangkan anakanak dan perempuan dewasa mendapatkan dua baju atau kaos setiap hari, dan balita mendapatkan tiga baju setiap hari.

$\mathrm{Y}=x_{1}+2 x_{2}+2 x_{3}+3 x_{4}$

$x_{1} \quad=$ jumlah baju untuk pria dewasa $1 \mathrm{bh} / \mathrm{hr}$

$x_{2}=$ jumlah baju untuk wanita dewasa $2 \mathrm{bh} / \mathrm{hr}$

$x_{3} \quad=$ jumlah baju untuk anak-anak $2 \mathrm{bh} / \mathrm{hr}$

$x_{4} \quad=$ jumlah baju balita $3 \mathrm{bh} / \mathrm{hr}$

Bantuan baju atau kaos diberikan kepada korban mengungsi selama pasca bencana yaitu lima hari.

- Celana panjang dan rok

Pria mendapatkan satu celana setiap hari sedangkan anak-anak mendapatkan dua buah setiap hari, dan wanita mendapatkan rok satu setiap hari.

$\mathrm{Y}=x_{1}+2 x_{2}+2 x_{3}+3 x_{4}$

$x_{1} \quad=$ jumlah celana untuk pria dewasa $1 \mathrm{bh} / \mathrm{hr}$

$x_{2} \quad=$ jumlah rok untuk wanita dewasa $2 \mathrm{bh} / \mathrm{hr}$

$x_{3}=$ jumlah celana untuk anak-anak $2 \mathrm{bh} / \mathrm{hr}$

$x_{4}=$ jumlah celana/rok balita $3 \mathrm{bh} / \mathrm{hr}$

Celana panjang dan rok diberikan kepada korban mengungsi selama pasca bencana yaitu lima hari.
- Celana dalam

Pria mendapatkan satu setiap hari sedangkan anak anak dan wanita mendapatkan dua celana dalam setiap hari.

$\mathrm{Y}=x_{1}+2 x_{2}+2 x_{3}+3 x_{4}$

$x_{1} \quad=$ jumlah celana dalam untuk pria dewasa $\quad 1 \mathrm{bh} / \mathrm{hr}$

$x_{2} \quad=$ jumlah celana dalam untuk wanita dewasa $2 \mathrm{bh} / \mathrm{hr}$

$x_{3}=$ jumlah celana dalam untuk anak-

anak $2 \mathrm{bh} / \mathrm{hr}$

$x_{4} \quad=$ jumlah celana dalam balita $3 \mathrm{bh} / \mathrm{hr}$

Celana dalam diberikan kepada korban mengungsi selama pasca bencana yaitu lima hari.

- Popok balita

Balita mendapatkan tiga popok setiap hari.

$\mathrm{Y}=3 x_{4}$

$x_{4} \quad=$ jumlah pakaian balita

Popok balita diberikan kepada korban mengungsi selama pasca bencana yaitu lima hari

Untuk setiap jenis logistik kebutuhan korban bencana yang akan di distribusikan terlebih dahulu dihitung volume ataupun berat dari tiap jenis logistiknya, agar lebih memudahkan untuk penentuan jumlah volume kendaraan ataupun jenis kendaraan yang akan digunakan. Berat ataupun volume tersebut dapat dilihat pada tabel 1 di bawah berikut:

Tabel 1. Berat Logistik Pangan dan Sandang

\begin{tabular}{|l|c|l|c|l|}
\hline \multicolumn{1}{|c|}{ Item Logistik } & \multicolumn{2}{|c|}{ beratper item } & \multicolumn{2}{c|}{ Berat perpack } \\
\hline Beras & 1 & $\mathrm{~kg}$ & 25 & $\mathrm{krg} / 25 \mathrm{~kg}$ \\
\hline M ie instant & 85 & $g r$ & 3.4 & $\mathrm{dus} / 40 \mathrm{bks}$ \\
\hdashline N ugget/Sarden & 155 & $g r / \mathrm{klg}$ & 7.75 & $\mathrm{dus} / 50 \mathrm{klg}$ \\
\hline Roti & 250 & $g r / \mathrm{bks}$ & 3 & $\mathrm{~kg} / \mathrm{dus} / 12 \mathrm{bks}$ \\
\hline A irm inum kem esan & 220 & $g r / \mathrm{gls}$ & 8.8 & $\mathrm{dus} / 40 \mathrm{gls}$ \\
\hline Berat jeans cow ok & 700 & $g r$ & 14 & $\mathrm{~kg} / \mathrm{kodi}$ \\
\hline Berat jeans cew ek & 500 & $g r$ & 10 & $\mathrm{~kg} / \mathrm{kodi}$ \\
\hline T shirt & 250 & $g r$ & 5 & $\mathrm{~kg} / \mathrm{kodi}$ \\
\hline Celana dalam & 80 & $g r$ & 1.6 & $\mathrm{~kg} / \mathrm{kodi}$ \\
\hline Popok Balita 46 Pieces & 131 & $g r$ & 6.026 & $\mathrm{~kg} /$ pieces \\
\hline
\end{tabular}

\section{ANALISIS DATA}

Hasil survei dari 11 kabupaten dan 7 kota yang ada disumatera barat yang akan digunakan sebagai parameter untuk memprediksi jumlah korban dengan metoda 
analisis regresi. Peramalan dengan menggunakan metode regresi dibutuhkan kandidat variabel bebas dan variabel tak bebas.
Variabel bebas umumnya merupakan faktorfaktor yang mempengaruhi variabel tak bebas seperti terlihat pada table 2 .

Tabel 2. Variabel Korban Bencana

\begin{tabular}{|c|c|c|c|c|c|c|c|c|c|c|c|c|}
\hline \multicolumn{3}{|c|}{ Korban Bencana } & \multicolumn{2}{|c|}{ Land U se } & \multicolumn{6}{|c|}{ In tensitas Bencana } & \multicolumn{2}{|c|}{ Pem aham an Bencana } \\
\hline$M$ en inggal & Luka Luka & M engungsi & $\begin{array}{l}\text { Jum lah } \\
\text { Penduduk }\end{array}$ & $\begin{array}{c}\text { Kepadatan } \\
\text { Penduduk (km 2) }\end{array}$ & $\begin{array}{l}\text { Raw an } \\
\text { Tsunam i }\end{array}$ & Tanah Longsor & Banj̈r & Kebakaran & $\begin{array}{l}\text { Abrasi } \\
\text { Pantai }\end{array}$ & $\begin{array}{l}\text { Angin Puting } \\
\text { Beliung }\end{array}$ & Baik & Kurang Baik \\
\hline $\mathrm{y}_{1}$ & $\mathrm{y}_{2}$ & $\mathrm{y}_{3}$ & $x_{1}$ & $\mathrm{x}_{2}$ & $\mathrm{x}_{7}$ & $\mathrm{x}_{8}$ & $x_{9}$ & $\mathrm{x}_{10}$ & $\mathrm{x}_{11}$ & $\mathrm{x}_{12}$ & $\mathrm{x}_{13}$ & $\mathrm{x}_{14}$ \\
\hline 725 & 13.5 & 2933 & 446479 & 77.05 & 0 & 42 & 63 & 24 & 32 & 0 & 47 & 47 \\
\hline 0 & 2.5 & 1889.5 & 361095 & 96.6 & 0 & 60 & 10 & 74 & 0 & 74 & 23 & 23 \\
\hline 2.5 & 0 & 3 & 218588 & 69.82 & 0 & 32 & 0 & 83 & 0 & 26 & 57 & 57 \\
\hline 3 & 0 & 0 & 343875 & 257.39 & 0 & 14 & 8 & 14 & 0 & 14 & 33 & 33 \\
\hline 226.67 & 1515 & 0 & 403530 & 303.68 & 8 & 14 & 14 & 14 & 8 & 0 & 46 & 46 \\
\hline 52.5 & 71 & 3279.5 & 472995 & 211.89 & 3 & 6 & 5 & 16 & 1 & 6 & 26 & 27 \\
\hline 0 & 0 & 0 & 365389 & 108.93 & 0 & 12 & 10 & 13 & 0 & 13 & 21 & 20 \\
\hline 2 & 3 & 903 & 266888 & 60.01 & 0 & 5 & 4 & 1 & 0 & 5 & 31 & 31 \\
\hline 3 & 0 & 2022 & 156901 & 46.89 & 0 & 34 & 19 & 39 & 0 & 39 & 11 & 10 \\
\hline 0 & 0 & 15 & 216928 & 7326 & 0 & 3 & 5 & 11 & 0 & 11 & 15 & 16 \\
\hline 2 & 30 & 2001 & 401624 & 118.55 & 5 & 1 & 13 & 19 & 5 & 0 & 57 & 57 \\
\hline 158 & 1202 & 147 & 889461 & 1280.02 & 24 & 1 & 15 & 69 & 7 & 15 & 89 & 86 \\
\hline 0 & 0 & 3591 & 64819 & 1124.55 & 0 & 0 & 9 & 12 & 0 & 0 & 8 & 7 \\
\hline 0 & 0 & 75 & 59608 & 217.99 & 0 & 24 & 7 & 8 & 0 & 0 & 15 & 0 \\
\hline 0 & 20 & 0 & 50208 & 2182.96 & 0 & 0 & 0 & 0 & 0 & 3 & 3 & 4 \\
\hline 0 & 4 & 233 & 120491 & 4773.81 & 0 & 12 & 4 & 13 & 0 & 3 & 16 & 0 \\
\hline 0 & 0 & 19 & 125690 & 1562.73 & 0 & 0 & 0 & 9 & 0 & 0 & 9 & 9 \\
\hline 32 & 426 & 0 & 83610 & 1139.72 & 4 & 3 & 4 & 4 & 3 & 4 & 27 & 30 \\
\hline
\end{tabular}

Kemudian data diolah dengan metode regresi berganda setelah melewati uji statistic untuk mengetahui variable variable apa yang digunkan dalam pemodelan. Metode ini dimulai dengan memasukan variable bebas yang memiliki korelasi paling kuat dengan variable terikat. Kemudian variable bebas yang

Tabel 3. Analisis Regresi Metoda Langkah Demi Langkah (coba coba)

\begin{tabular}{|c|c|c|c|c|c|c|c|c|c|c|c|}
\hline \multirow{2}{*}{ Peubah } & \multirow{2}{*}{\begin{tabular}{|} 
Tanda yang \\
dinarapk kan
\end{tabular}} & \multicolumn{5}{|c|}{ Tahap } & \multicolumn{5}{|c|}{ Tahap } \\
\hline & & 1 & 2 & 3 & 4 & 5 & 10 & 11 & 12 & 13 & 14 \\
\hline Intercoep & ++- & 203121 & 465,37 & 204.61 & -328.47 & 749.36 & 799.78 & 941.73 & 401.81 & 696.90 & 438.87 \\
\hline X1, um lah Penduduk & + & -0.01 & & & & & & & 0.00 & & \\
\hline X2, Kepadatan Penduduk (km 2) & + & 021 & 0.16 & 0.15 & 0.21 & -0.40 & -0.30 & -0.35 & & -0.31 & -0.15 \\
\hline X3,Pelayanan Kesehatan & + & 13.92 & 2.87 & 2.94 & 6.06 & 3.19 & & & & & \\
\hline$X 4$, Peralatan Evakuasi & + & -9.32 & -8.05 & -828 & & & & & & & \\
\hline$X 5, P D R B$ H arga Constan (utta $R p)$ Ka & + & -5028 & 8.01 & & & & & & & & \\
\hline$X 6, G$ em pa Bum $i$ & + & 48.75 & 6725 & 67.03 & 65.49 & 3.19 & 4224 & 40.01 & 14.55 & 42.51 & 17.36 \\
\hline X7, Rawan $T \operatorname{sunam} i$ & + & 360.11 & 134.93 & 129.60 & 11321 & 46.98 & -42.87 & & & & \\
\hline X8,Tanah Longsor & + & -12.79 & 17.72 & 17.71 & 37.70 & -60.34 & -51.40 & -4620 & & -46.41 & \\
\hline$x 9$, Banjir & + & 249.78 & 211.83 & 215.41 & 224.35 & -98.36 & 47.05 & 47.48 & 37.58 & 43.43 & 31.80 \\
\hline X10, Kebakaran & + & 86.05 & 61.33 & 60.32 & 72.01 & 113.92 & & & & & \\
\hline X11,AbrasiPantai & + & -512.80 & -447.64 & -453.13 & -524.36 & 56.92 & & & & & \\
\hline X12, Angin Puting Belizing & + & -190.62 & -16922 & -168.07 & -210.10 & -109.43 & & & & & \\
\hline X13,Baik & + & -211.69 & -253.64 & -254.47 & -28922 & & & & & & \\
\hline X14,Kurang Baik & + & 153.79 & 220.62 & 223.63 & 245.48 & -30.74 & 1.30 & -7.84 & -10.53 & & \\
\hline & $\overline{\mathrm{R}^{2}}$ & 0.81 & 0.79 & 0.79 & 0.76 & 0.62 & 0.45 & 0.44 & 0.30 & 0.43 & 0.31 \\
\hline & $\mathrm{F}$ & 0.89 & 1.13 & 1.53 & 1.69 & 1.14 & 1.52 & 1.89 & 1.40 & 2.41 & 2.07 \\
\hline
\end{tabular}

Berdasarkan kriteria yang telah ditentukan, model terpilih untuk analisis coba-coba adalah tahap ke-12.

Berdasarkan kriteria yang ada, model terbaik dari 14 kombinasi yang ada adalah model kombinasi ke 12. Terdapat 3 variabel bebas bernilai positif yaitu jumlah penduduk, gempa bumi, banjir dan variabel nilai negatif tidak mempunyai korelasi dengan variable terikat dikeluarkan dan tidak digunakan dalam pemodelan. Berdasarkan hasil tahap demi tahap dan dilakukan proses langkah demi langkah tipe-3 (analisis coba-coba). Hasil pemodelan ini dapat dilihat tabel 3. yaitu pemahaman bencana kurang baik. Ada beberapa alasan yang menyebabkan model tahap 12 yang dipilih sebagai persamaan regresi dalam menentukan korban mengungsi pasca bencana adalah sebagai berikut:

- Meskipun nilai $R^{2} \quad(0,30)$ yang dihasilkan bukanlah yang tertinggi, namun tanda regresi variabel 
bebasnya sesuai dengan yang diharapkan (nilai positif/negatif).

- Nilai konstanta regresi (intersep) sebesar 401,81 paling rendah di bandingkan dengan nilai lain.

- Variabel $x_{I}$ sebesar 0,001 berarti setiap bertambah jumlah penduduk akan semakin bertambah jumlah korban mengungsi.

- Variabel $x_{6}$ sebesar 14,55 berarti semakin sering terjadi bencana gempa bumi akan semakin besar jumlah korban mengungsi.

- Variabel $x_{9}$ sebesar 37,55 berarti fluktuasi banjir lebih tinggi dari gempa bumi dan semakin sering terjadi bencana banjir semakin besar jumlah korban mengungsi.

- Variabel $x_{14}$ sebesar $-10,53$ yang berarti pertambahan jumlah penduduk, tingginya fluktuasi gempa bumi dan banjir akan berkurangnya jumlah masyarakat yang awam terhadap bencana.

Berdasarkan table model langkah demi langkah analisis coba-coba di atas dapat disusun suatu persamaan regresi linear berganda sebagai berikut:

Persamaan regresinya:

Tabel 4. Hasil Prediksi Korban Mengungsi

\begin{tabular}{|c|c|c|c|c|c|c|c|c|c|}
\hline \multirow{2}{*}{ Nam a Kab/Kota } & \multicolumn{9}{|c|}{ Tahun } \\
\hline & 2018 & 2019 & 2020 & 2021 & 2022 & 2023 & 2024 & 2025 & 2030 \\
\hline Pesisir Selatan & 5446.3 & 5937.5 & 6428.6 & 6919.8 & 7410.9 & 7902.1 & 83932 & 8884.4 & 11340.1 \\
\hline Solok (kayu aro) & 2911.1 & 3219.3 & 3527.4 & 3835.6 & 4143.7 & 4451.8 & 4760.0 & 5068.1 & 6608.8 \\
\hline Sijunjung & 199.7 & 208.7 & 217.8 & 226.8 & 235.8 & 244.8 & 253.9 & 262.9 & 308.0 \\
\hline Tanah D atar & 997.7 & 1050.5 & 11032 & 1156.0 & 1208.7 & 1261.5 & 13142 & 1367.0 & 1630.7 \\
\hline Padang Pariam an & 666.5 & 614.5 & 562.5 & 510.5 & 458.4 & 406.4 & 354.4 & 302.4 & 42.3 \\
\hline A gam & 1483.0 & 1582.4 & 1681.8 & 1781.3 & 1880.7 & 1980.1 & 2079.5 & 2178.9 & 2675.9 \\
\hline Lim a Puluh Kota & 3060.6 & 3140.7 & 3220.7 & 3300.8 & 3380.8 & 3460.9 & 3540.9 & 3621.0 & 4021.3 \\
\hline Pasam an $\mathrm{T}$ in ur & 443.4 & 466.2 & 489.0 & 511.8 & 534.6 & 557.4 & 5802 & 603.0 & 717.0 \\
\hline Solok Selatan & 2478.1 & 2705.8 & 2933.5 & 31612 & 3388.9 & 3616.6 & 3844.4 & 4072.1 & 5210.6 \\
\hline D ham asraya & 17782 & 1774.4 & 1770.6 & 1766.7 & 1762.9 & 1759.1 & 1755.3 & 1751.5 & 1732.4 \\
\hline Pasam an Barat & 4171.8 & 4261.6 & 4351.3 & 4441.0 & 4530.7 & 4620.4 & 4710.1 & 4799.8 & 5248.3 \\
\hline Padang & 851.9 & 861.9 & 872.0 & 882.0 & 892.1 & 902.1 & 912.1 & 9222 & 972.4 \\
\hline Solok (kota) & 980.3 & 1112.9 & 1177.8 & 1242.7 & 1307.6 & 1372.5 & 1437.4 & 1502.3 & 1826.9 \\
\hline Saw ah Lunto & 1392.7 & 1453.0 & 1513.4 & 1573.7 & 1634.0 & 1694.4 & 1754.7 & 1815.1 & 2116.8 \\
\hline Padang Panjang & 801.3 & 812.0 & 822.7 & 833.4 & 844.1 & 854.8 & 865.5 & 8762 & 929.8 \\
\hline Bukittinggi & 617.4 & 623.5 & 629.6 & 635.7 & 641.8 & 647.9 & 654.0 & 660.1 & 690.7 \\
\hline Payakum buh & 864.9 & 888.0 & 9112 & 934.3 & 957.5 & 980.6 & 1003.8 & 1026.9 & 1142.7 \\
\hline Pariam an & 369.9 & 329.4 & 288.8 & 248.3 & 207.71085 & 167.15378 & 126.5967 & 86.039623 & -116.7458 \\
\hline
\end{tabular}

Dari tabel 4. hasil prediksi korban korban mengungsi pasca bencana dapat dilihat jumlah korban mengungsi terbanyak terdapat

$\begin{array}{cccccc}Y= & + & + & + & - & \\ 401,8 & 0.001 & 14,5 & 37.5 & 10.53 & \\ 1 & x_{1} & 5 x_{6} & 8 x_{9} & x_{14} & \\ S E= & 0,002 & 14,2 & 37,7 & 23,61 & R^{2}=0 \\ 565,3 & 59 & 09 & 57 & 4 & , 3 \\ 77 & & & & & \\ t-\text { Stat } & 0,280 & 0,95 & 1,56 & - & F=1, \\ = & & 6 & 5 & 0,446 & 39\end{array}$

Setelah dilakukan pengujian model, didapatkan bahwa faktor yang mempengaruhi jumlah korban mengungsi di Propinsi sumatera barat terdapat empat variable yang memiliki korelasi paling kuat terhadap variable terikat korban mengungsi (y3), yaitu jumlah penduduk (x1), bencana gempa bumi (x2), bencana banjir (x3) dan pemahaman bencana kurang baik (x4)

\section{HASIL ANALISA DATA}

Tabel dibawah ini merupakan hasil olah data yang memperlihatkan bahwa terdapat Hasil prediksi jumlah korban mengungsi korban bencana di Propinsi Sumatera Barat dari tahun 2018 sampai dengan 2030, sebagai berikut:
2018 terdapat 5414,7 orang pengungsi dan terus naik setiap tahunya sampai pada tahun 
2030 sebesar 11308,5 orang, rata rata pertumbuhan korban mengungsi setiap tahunya $0,043 \%$ atau 491 orang/tahunya. Beda halnya dengan Kota Pariaman yang mengalami penurunan yang sangat besar 0,02
$\%$ pertahunya dan ditahun 2022 hingga 2030 Kota Pariaman tidak ada korban jiwa.

Peningkatan dan penurunan korban bencana dari tahun 2018 sampai dengan 2030 dapat dilihat pada gambar dibawah sebagai berikut:

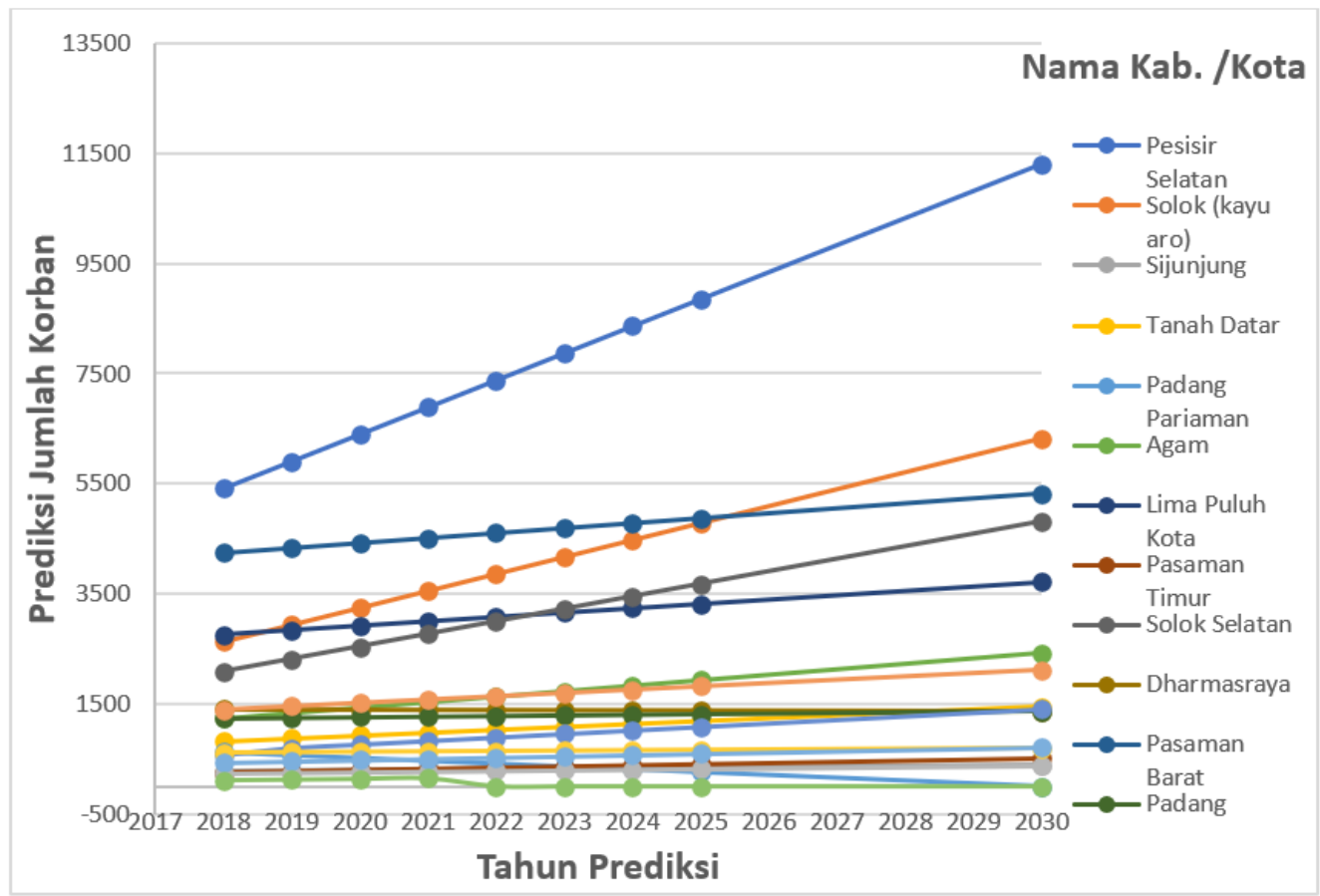

Gambar 3. Hasil Prediksi Korban Mengungsi

Hasil prediksi korban mengungsi pasca bencana berdasarkan gambar di atas dapat dilihat bahwa, Kabupaten yang mengalami peningkatan jumlah korban tertinggi adalah Kab. Pesisir selatan, Kab. Solok dan Kab. Solok Selatan. Sedangkan Kab. Pasaman Barat, Kab. Lima Puluh Kota dan Kota Solok mengalami peningkatan sedang. Namun beda halnya dengan Kota Pariaman dan Padang Pariaman mengalami penurunan.

Kebutuhan logistik bantuan bencana yang diprediksi terdiri atas bantuan logistik pangan dan sandang, dari hasil prediksi dilakukan dari tahun 2018 sampai dengan tahun 2030 terlihat bahwa, jumlah kebutuhan tiap tahunnya terus meningkat. Hasil prediksi tahun 2018 diperoleh sebesar 538,13 ton, pada tahun 2030 terus meningkat menjadi 908,25 ton, atau meningkat sebesar $30,84 \%$ (rata-rata peningkatan tiap tahunnya $3,4 \%$ ). Peningkatan pada logistik pangan sebesar $18,93 \%$ (ratarata peningkatan tiap tahunnya $3,41 \%$ ) dan pada logistik sandang sebesar $11,90 \%$ (ratarata peningkatan tiap tahunnya $3,33 \%$ ). Untuk lebih jelasnya dapat dilihat pada tabel 4.6 dibawah berikut: 
Tabel 5. Prediksi Volume Logistik

\begin{tabular}{|c|c|c|c|c|c|c|c|c|c|}
\hline \multirow{2}{*}{$\mathrm{N}$ am a Kab/Kota } & \multicolumn{9}{|c|}{ Tahun Prediksi } \\
\hline & 2018 & 2019 & 2020 & 2021 & 2022 & 2023 & 2024 & 2025 & 2030 \\
\hline Pesisir Selatan & 111.77 & 121.85 & 131.92 & 142.00 & 152.08 & 162.16 & 172.24 & 182.32 & 232.72 \\
\hline Solok (kayu aro) & 59.74 & 66.06 & 72.39 & 78.71 & 85.03 & 91.36 & 97.68 & 104.01 & 135.62 \\
\hline Sijunjung & 4.03 & 428 & 4.39 & 4.65 & 4.84 & 5.02 & 521 & 5.64 & 6.32 \\
\hline T anah D atar & 20.47 & 21.56 & 22.64 & 23.72 & 24.80 & 25.89 & 26.97 & 28.05 & 33.47 \\
\hline Padang Pariam an & 11.92 & 12.61 & 11.54 & 10.48 & 9.41 & 8.34 & 727 & 6.21 & 0.87 \\
\hline A gam & 30.43 & 32.47 & 33.88 & 36.55 & 38.59 & 40.63 & 42.67 & 44.71 & 54.91 \\
\hline Lim a Puluh Kota & 62.81 & 64.45 & 66.09 & 67.74 & 69.38 & 71.02 & 72.67 & 74.31 & 82.52 \\
\hline Pasam an Tim ur & 9.10 & 9.57 & 10.04 & 10.50 & 10.97 & 11.44 & 11.91 & 12.38 & 14.19 \\
\hline Solok Selatan & 50.85 & 55.53 & 59.32 & 64.87 & 69.55 & 74.22 & 78.89 & 83.57 & 106.93 \\
\hline D harm asraya & 3628 & 36.41 & 36.33 & 3626 & 36.18 & 35.89 & 36.02 & 35.94 & 35.55 \\
\hline Pasam an Barat & 85.61 & 87.45 & 8929 & 91.14 & 92.98 & 94.82 & 96.66 & 98.50 & 107.70 \\
\hline Padang & 17.48 & 17.69 & 17.63 & 17.77 & 18.31 & 18.51 & 18.72 & 18.92 & 19.95 \\
\hline Solok (kota) & 20.12 & 22.84 & 24.17 & 25.50 & 26.83 & 28.32 & 29.50 & 30.83 & 37.49 \\
\hline Saw ah Lunto & 28.58 & 29.82 & 30.87 & 3229 & 33.53 & 34.77 & 36.01 & 3725 & 43.44 \\
\hline Padang Pan jang & 16.44 & 16.66 & 16.88 & 17.10 & 17.32 & 17.54 & 17.76 & 17.98 & 19.08 \\
\hline Bukittinggi & 12.67 & 12.79 & 12.92 & 13.05 & 13.17 & 13.30 & 13.42 & 13.55 & 14.17 \\
\hline Payakum buh & 17.75 & 1822 & 18.70 & 19.17 & 19.65 & 20.12 & 20.60 & 21.07 & 23.45 \\
\hline Pariam an & 7.59 & 627 & 5.82 & 5.09 & 426 & 3.43 & 223 & 1.77 & -2.40 \\
\hline
\end{tabular}

Berdasarkan tabel di atas dapat dilihat jumlah kebutuhan logistik tiap daerah yang ada di Sumatera Barat pada tahun 2018 sampai dengan 2030. Setiap tahunya kebutuhan logistik terus meningkat, seperti halnya Kab. Pesisir Selatan dengan jumlah kebutuhan terbanyak yaitu 232,07 ton pada tahun 2030 (rata- rata peningkatan tiap tahunya $4,3 \%$ atau 10,07 ton). Kemudian disusul pada Kab. Solok sebesar 129,79 ton dengan rata rata peningkatan tiap tahunya $4,9 \%$, Kab. Pasaman Barat 109,22 ton dan Kab. Solok Selatan 98,8 ton dan Kab. Lima Puluh Kota sebesar 76,3 ton. Namun beda halnya pada Kab. Padang
Pariaman dan Kota Pariaman yang mengalami penurunan. Hasil prediksi kebutuhan logistik Kab. Padang Pariaman pada tahun 2018 sebesar 11,16 ton, sampai dengan pada tahun 2030 kebutuhan nol (rata- rata penurunan tiap tahunya $211,75 \%$ atau 0,93 ton). Sama halnnya dengan Kota Pariaman yang mengalami penurunan drastis, prediksi kebutuhan pada tahun 2018 sebesar 2,24 ton sampai dengan tahun 2022 kebutuhan nol (rata rata penuruanan tiap tahunya $18,6 \%$ ). Untuk lebih jelasnya dapat dilihat pada gambar dibawah berikut ini: 


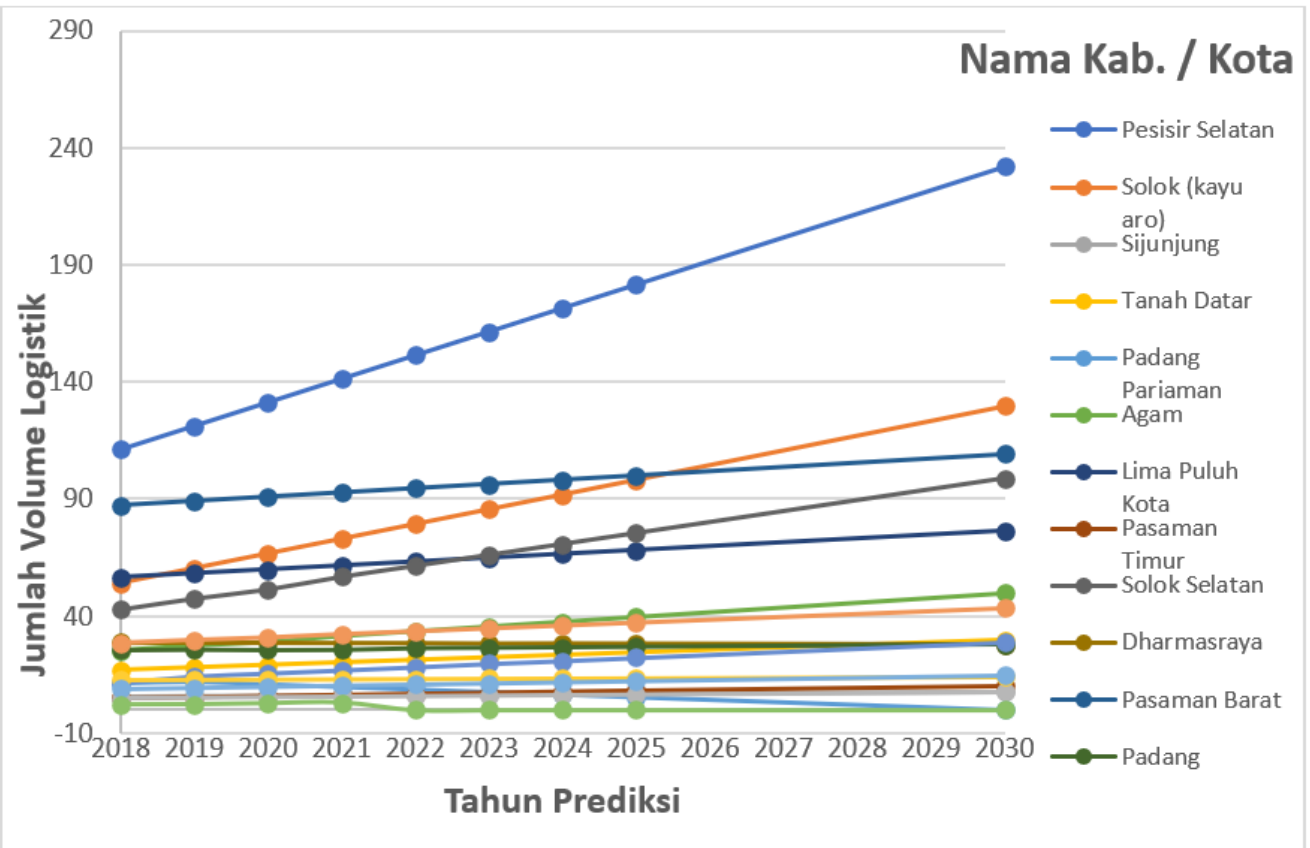

Gambar 4. Prediksi Kebutuhan Logistik

Logistik bantuan bencana terdiri dari kebutuhan pangan yang berupa beras, mie instant, nugget/ sarden, roti dan air minum kemasan, sedangkan kebutuhan sandang berupa baju, celana/ rok, celana dalam dan popok balita. Hasil prediksi jumlah kebutuhan logistik bencana pada tahun 2018 sampai dengan 2030 tiap item logistik dapat dilihat pada Gambar 5. dibawah berikut:

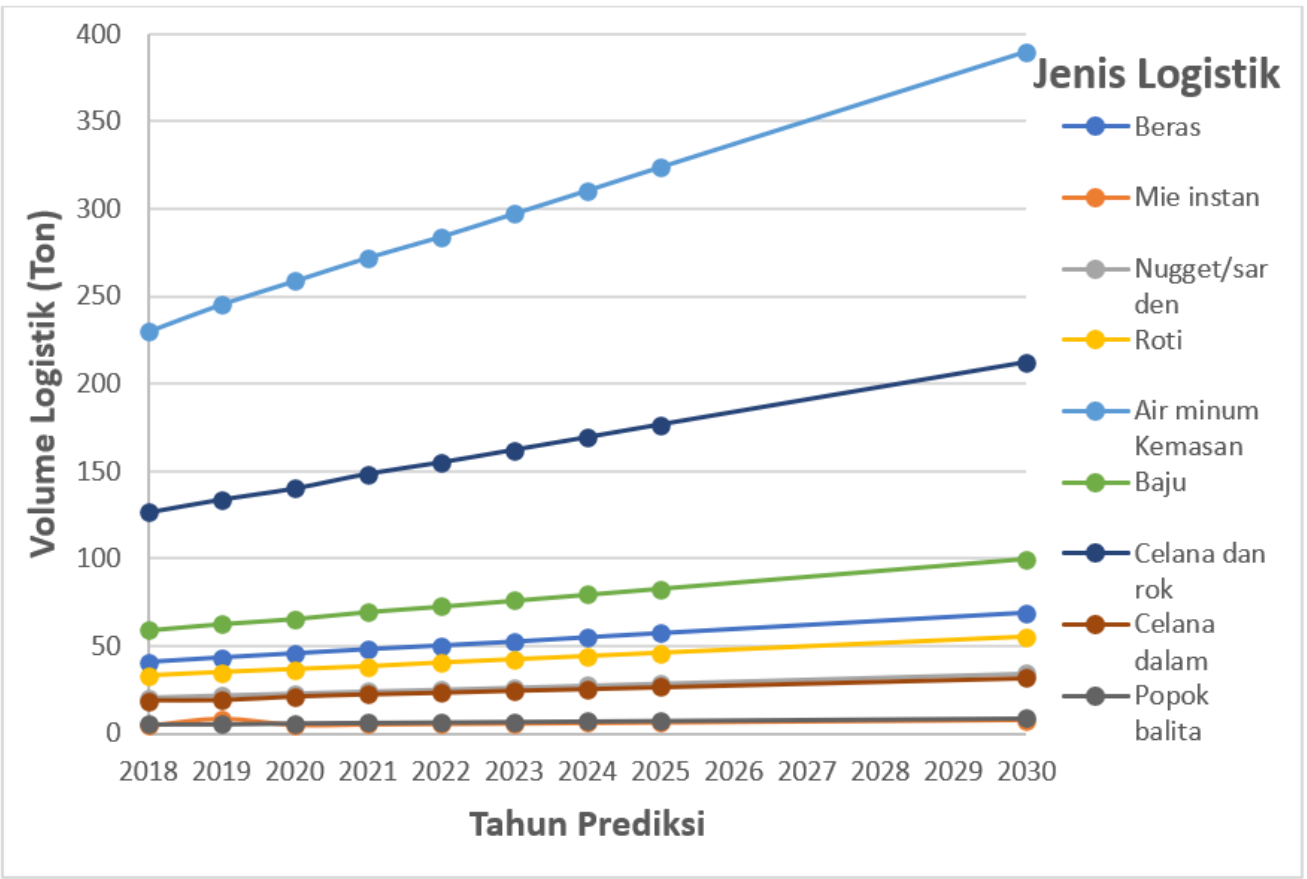

\section{Gambar 5. Jumlah Volume Peritem Logistik}

Dari gambar di atas merupakan hasil prediksi kebutuhan logistik pasca bencana di Sumatera Barat pada tahun 2018 sampai dengan 2030, dapat dilihat jumlah volume tiap jenis logistik mengalami peningkatan tiap tahunnya. Kebutuhan pangan terbanyak terdapat pada air minum kemasan dan beras, sedangkan pada kebutuhan sandang baju dan celana. Rata-rata peningkatan kebutuhan pangan 3,4\%/ tahunnya atau sebesar 18,93 ton/ tahunya, sedangkan rata-rata peningkatan 
kebutuhan sandang 3,3\%/ tahunnya atau sebesar 11,9 ton/ tahun.

\section{SIMPULAN}

Dari hasil analisis data yang telah dilakukan maka dapat disimpulkan bahwa besarnya jumlah korban mengungsi $(y)$ pasca bencana di sumatera barat dipengaruhi oleh jumlah penduduk $\left(x_{1}\right)$, fluktuasi bencana gempa bumi $\left(x_{6}\right)$, fluktuasi banjir $\left(x_{9}\right)$ dan pemahaman masyarakat terhadap bencana yang rendah $\left(x_{14}\right)$. Model terbaik untuk memprediksi jumlah korban bencana di Sumatera Barat adalah $y=401,81+(0.001) x_{1}+$ $(14,55) x_{6}+(37.58) x_{9}+(-10.53) x_{14}$ dengan nilai $\mathrm{R}^{2}$ sebesar 0,30 . Dengan nilai variabel bebasnya adalah dalam bentuk tahun (data 2010, 2011, 2012 dan 2014).

Hasil prediksi jumlah logistik bantuan bencana berdasarkan data jumlah korban pada tahun 2015, diperoleh jumlah volume logistik bantuan Sumatera Barat sebesar 446,82 ton pada tahun 2018. Bila dilihat hasil prediksi logistik bantuan pada tahun 2018 sampai dengan 2030 mengalami proses peningkatan dengan jumlah volume sebesar 621,43 ton atau meningkat sebesar $28,1 \%$, rata-rata peningkatan tiap tahunnya $2,3 \%$.

\section{DAFTAR PUSTAKA}

Arief dkk., (2012). Pengembangan Model Distribusi Barang Batuan Kepada Korban Bencana Dengan Transportasi Darat Menggunakan Sistem Dinamik.Jurnal Teknik Industri, Institut Teknologi Sepuluh Nopember Surabaya. http://digilib.its.ac.id (Diakses pada tanggal 10 Februari 2016).

Ariyana., (2012), Model Lokasi-Alokasi Bantuan Logistic Catastrophic Berbasis , Volume 11, No Masjid di Kota Padang. Jurnal Teknik Industri, Universitas Andalas 12, Hal 235-242, Padang. (Diakses pada tanggal 10 Februari 2016). http://industri.ft.unand.ac.id

Badan Nasional Penanggulanga Bencana, (2009), Data Informasi dan BencanaIndonesia.

http://dibi.bnpb.go.id. (Diakses pada tanggal 10 Februari 2016).

BNPB, 2012, National Action Plan for Disaster Risk Reduction, Jakarta.
BNPB, 2012, National Action Plan for Disaster Risk Reduction, Jakarta

Gottfried, B. S., (1984). Elemen of Stochastik Process Simulastion. Prentice hall, inc. New Jersey.

Hadiguna.,Wibowo. (2012). Simulasi Sistim Logistic Bantuan Bencana GempaTsunami: Studi Kasus Kota Padang. Jurnal Teknik Industri, Vol 13, No 2. Universitas Negeri Andalas. http://industri.ft.unand.ac.id. (Diakses pada tanggal 10 Februari 2016).

Hehanussa, Priska Eudia., (2012). Perancangan Jaringan Logistik untuk Menentukan Lokasi dan Jumlah Gudang Penyalur Berbasis Peta Risiko Bencana di Kabupaten Sleman, Daerah Istimewa Yogyakarta. Jurnal Teknik Industri. Universitas Atma Jaya Yogyakarta.http://ejournal.uajy.ac.id/90/(Diakses pada tanggal 10 Februari 2016).

Perka BNPB., No 4 Tahun 2009, Pedoman Bantuan Logistik. www.bnpb.go.id (Diakses pada tanggal 10 Februari 2016).

Perka BNPB., No 13 Tahun 2008, Karakteristik Sistem Logistik Bencana. www.bnpb.go.id. (Diakses pada tanggal 10 Februari 2016).

Perka BNPB., No 10 Tahun 2012, Pengelolaan Bantuan Logistic Pada Status Keadaan Darurat Bencana.www.bnpb.go.id (Diakses pada tanggal 10 Februari 2016).

Tamin, (2003), Perencanaan dan Pemodelan Transportasi, Edisi ke-2, Bandung, Penerbit ITB.I

Thomas. A, (2003), Humanitarian Logistics: Enabling Disasters Response ,pp 15,Fritz-Institute.

www.fritzinstitute.org/pdfs/whitepaper/enablin gdisasterresponse.pdf.(Diakses pada tanggal 10 Februari 2016). 